\title{
Business Analysis on Sweet Condensed Tempeh as a Functional Food
}

\author{
Firman Tri Ajie, Adityo Wicaksono, Tommy Hendrix \\ Pusat Inovasi \\ LIPI \\ Bogor, Indonesia \\ firm001@lipi.go.id
}

\author{
Muhammad Angwar \\ UPT Balai Penelitian Teknologi Bahan Alam \\ LIPI \\ Bogor, Indonesia
}

\begin{abstract}
In recent years, a growing interest in foods of plant origin, especially plant protein foods, has become evident. The oriental soybean foods have appeared all over the world. Tempeh, one of soybean protein food, is one of popular Indonesian soybean food made from yellow soybean by fermentation with a mold, Rhizopus sp. The fermentation eliminates the beany flavor of raw soybeans and gives the product a flavor which is bland but attractive. This food is digestible and more nutritious than plain cooked soybeans. Indonesian Institute of Sciences (LIPI) develop products derived from tempeh, as tempeh known as product that is easily damaged. Sweet Condensed tempeh is a product-based research tempeh which has the advantages of a raw material compared to similar products. This study will give a clear perspective, regarding the development of new research-based tempeh products. This study is using mix method, a combination between quantitative and qualitative method. The qualitative analysis using Porter's Five Forces, indicated that Sweet Condensed tempeh has the opportunity as a new product that can survive in the market. The result shown that cash flow analysis of the projected sweet condensed has demonstrated that the operation of the plant would be financially feasible.
\end{abstract}

Keyword: Tempeh, Sweet Condensed Tempeh, New Product Development, Porter's Five Forces.

\section{INTRODUCTION}

Tempeh is an Indonesian traditional food made from soybean with its attractive flavor, mixed of fungi and soybean flavor, texture and superior digestibility. The mould grow during tempeh fermentation knit the bean together into a compact sliceable cake. Tempeh has become a daily diet of Indonesian people for hundreds of years. Beside its excellent nutrition quality, tempeh has also known as a source of bioactive compound such as antioxidant. The outstanding characteristic of tempeh has made tempeh becoming more popular not limited to vegetarians. Tempe is considered to be originated from Java. In general, tempeh is produced by small scale at home industries with poorly controlled fermentation process that causes the variation of tempeh flavors, for example bitter taste often appears in tempeh [1]. To improve the quality of tempeh, quality control must be carried out starting from starter culture production throughout tempeh fermentation. Rhizopus oligosporus is the main microorganism plays important role in tempeh fermentation process. Besides fungi, other microorganisms may also participate in tempeh fermentation process [1] [2].

In this paper, we trying to disclose business development of patent based. Sweet condensed tempeh is one of technology which has been registered at the Ministry of Justice and human rights with the registration number P00200600037 and certified number IDP000037654. The technology is effected by the growing number of processed products in the form of sweetened condensed milk, both product based from animal milk or vegetable milk is easy to find in the market.

This product, made from fresh tempeh with fermentation level of maturity about $90 \%$ or more. The manufacturing process can be explained in a simple, fresh tempeh washed and drained the fresh tempeh in room temperature and keep in the clean area. After that the process continued to slicing, blanching on $60-70 \mathrm{oC}$. The time required in the process of blanching is about 5 minutes, this is to keep the microbes that reside in the tempeh becomes inactive. The next process is pulping, the process is carried out at a temperature of $60-72^{\circ} \mathrm{C}$ for 30 minutes, then do the conditioning process for 10-14 hours and continued with second heating process in the same previous condition. [3]

There are several step of evaporation process on this production, the main goal is to sterilize and condensed into 25$30 \%$ of solution. The final composition of sweet condensed tempeh consists of tempeh extract mixed with sugar or natural sweetener and other additional materials such as flavoring, coloring or other substances. Comparison of composition is 35$36.5 \%$ extract of tempeh: $60-62.5 \%$ Sweeteners: $1-5 \%$ of flavor, color or other materials. [3]

Sweet condensed tempeh, actually has a positioning as product substitution for vegetarians who have less choice of beverage products high in protein. Although the beverage products high in protein such as soy milk that becomes one of the popular products by vegetarian groups. However, it have the disadvantage of storage time product and digestibility, known as derived from soy beans that still has a long chain of amino acids because of that, soy milk is not easily to digest than sweet condensed tempeh.

\section{METHODOLOGY}

This study use mix methodology, its current status combines performance aspects of qualitative and quantitative in whole or 
in part from the steps of this research. Both of these methods can be combined with the following notes:

1. Can be used together to scrutinize the object are the same, but different purposes;

2. This is used in interchangeably;

3. Research methods cannot be combined because a different paradigm, but in quantitative research data collection techniques can be used (not his);

4. Can use these methods simultaneously as long as it can be clearly understood and experienced in conducting research. [4]

The quantitative analysis by economic viability analysis of setting up a sweet condensed tempeh plant, with a capacity of producing 1,000 cans of sweet condensed tempeh per day. And as a complementary and the qualitative analysis using Porter's Five Forces which provides a convenient framework for exploring the economic factors that affect the profits and prices of an industry

\section{ANALYSIS AND RESULT}

\section{Sweet Condensed Tempeh Production Process}

This technology is actually quite simple to make. The manufacturing process starts from the sorting of raw materials $\sim$ fresh tempeh $\sim$ with fermentation level of maturity about $90 \%$. Then washed and drained the fresh tempeh in room temperature and keep in the clean area. After that the process continued to slicing, blanching, pulping and pasteurized. After mush tempeh formed, the next stage is filtering the tempeh pulp. After that, the process of evaporating and continued the process of sterilization and packaging.

\section{Economic Viability Analysis}

- Scope

The plant will aim to produce 1,000 cans of sweet condensed tempeh per day. This will require $50 \mathrm{Kg}$ of tempeh.

- Location

The location is Gunung Kidul - Yogyakarta.

- Production Capacity

The production Capacity of 1,000 cans of sweet condensed tempeh per day, about $50 \mathrm{~kg}$ tempeh is required. The current selling prices of products manufactured is IDR12,000/can.

One of the tools used to determine the feasibility of a technology is Discounted Cash Flow Method (DCF Method). In drawing up the DCF, several things need to be done to be able to draw conclusions the feasibility of a project is to do a cash flow projection, calculation of NPV, Internal Rate of Return, Benefit Cost Ratio and Payback period. [5]

NPV is the difference between the total income accruing, compared to the cost accumulated at present. It measures the excess or short fall of cash flow in present value terms. The formula can be written as follows:

$$
\mathbf{N P V}=\mathbf{Z}(\mathbf{B}-\mathbf{C t}) /(\mathbf{1}+\mathbf{i})
$$

Whereas:

$\mathrm{B}=$ Benefit $/$ Revenue

$\mathrm{C}=\mathrm{Cost}$

$$
\begin{aligned}
& \mathrm{i}=\text { interest } \\
& \mathrm{t}=\text { Time frame }
\end{aligned}
$$

As a result The NPV for production of sweet condensed tempeh is IDR 4,646,045,254. This means that the production of sweet condensed tempeh would add a value of IDR $4,646,045,254$ to the firm, and that therefore, the investment would be viable

IRR is the rate of return on an investment. The IRR of a project is the discount rate that will give it a net present value of zero. It is used to evaluate the desirability of investments or projects, and is an indicator of the efficiency, quality, or yield of an investment. This is in contrast to the NPV, which is an indicator of the value of an investment. The formula to calculate IRR is as follows:

$$
\operatorname{IRR}=\mathrm{Z}\{(\mathrm{B}-\mathrm{Ct}) /(\mathbf{1 + i}) *\}
$$

As a result, The IRR for production of sweet condensed tempeh is $46.33 \%$, which is greater than the established minimum acceptable rate of return or cost of capital ( $8 \%$ hurdle rate). Therefore, an investment in producing these products simultaneously is considered acceptable.

$\mathrm{BCR}$ reflects the ratio of how much profit (if any) will result from an investment. It is calculated by taking the net present value of expected future cash flows from the investment and dividing by the investment's original value. The formula to calculate BCR can be written as follows:

$$
\mathbf{B C R}=\mathbf{Z}\left\{\mathbf{B} /(\mathbf{1}+\mathbf{i})^{\circ}\right\} / \mathbf{Z}\left\{\mathbf{C}, /(1+\mathbf{i})^{\circ}\right\}
$$

As a result, The BCR for production of sweet condensed tempeh is 1.42 , indicating that the investment will be profitable because the BCR value is more than 1. BCR is also referred to as a profitability index.

The payback period is the time taken to recover the initial investment. Based on the cumulative gross profit and depreciation, an IDR 1.35 billion initial investment that will make an average gross profit of IDR 0.9 billion a year and average depreciation IDR 80 million a year has a payback period of less than 2 years. Investments with a shorter payback period are preferred to those with a long period. Most companies using payback period as criteria will have a maximum acceptable payback period for investment decisions

Based on these four criteria, financing the development of a sweet condensed tempeh production plant is considered to be a viable investment decision.

In addition, the study was done on the simulation analysis of the sensitivity. Sensitivity analysis is a technique for systematically changing variables in a model to determine the effects of such changes. In any budgeting process there are always variables that are uncertain. Future tax rates, interest rates, inflation rates, headcount, operating expenses and other variables may not be known with great precision. Sensitivity analysis answers the question: If these variables deviate from expectations, what will the effect be on the business, model, system, (or whatever is being analyzed)?" It can be useful to support decision making or the development of recommendations/strategies for decision makers. 


\section{PRESS}

For this reason, 10 scenarios, including increase/decrease of costs and prices at different percentages were used to stimulate the effect to NPV, IRR, BCR and payback period. Results show that if there is an increase in fixed costs, values for NPV, IRR and BCR will still be positive but the negative trend started when production costs increased by $50 \%$ and selling price decreased by $35 \%$, this indicates that the product is quite prone to distractions especially when production costs already exceeded $25 \%$ without increasing production capacity offset. It can be concluded that the production could not survive if production costs exceed $25 \%$ and selling price decreased more than $25 \%$.

However, results demonstrate that with an increase of $25 \%$

Table 1 . Sensitivity analysis for different scenarios in operating costs, NPV is reduced from IDR 4.65 billion to IDR 2.03 billion, IRR is reduced from $46.33 \%$ to $25.21 \%$ and $\mathrm{BCR}$ is reduced from 1.42 to 1.32 . Moreover, the payback period still around 2 years. NPV values become negative if operating costs are increased by $50 \%$. These scenarios demonstrate the importance for the company of controlling their operating costs, especially with regard to raw materials and packaging, in order to sustain their investment and profitability. The sensitivity analysis also indicates that selling price for sweet condensed tempeh cannot be reduced by more than $25 \%$ from the current price.

\begin{tabular}{|c|c|c|c|c|c|}
\hline \multicolumn{2}{|l|}{ Scenario } & NPV & IRR & BCR & Payout Period (Years) \\
\hline \multicolumn{2}{|l|}{ Baseline } & $4,646,045,254$ & $46.33 \%$ & 1.42 & 1.26 \\
\hline \multirow[t]{3}{*}{ Fixed Capital Investment Increased by. } & $25 \%$ & $3,154,501,817$ & $30.84 \%$ & 1.32 & 1.84 \\
\hline & $50 \%$ & $2,647,947,663$ & $24.92 \%$ & 1.28 & 2.23 \\
\hline & $75 \%$ & $2,141,393,509$ & $20.31 \%$ & 1.25 & 2.62 \\
\hline \multirow[t]{3}{*}{ Production Cost Increased by.. } & $25 \%$ & \begin{tabular}{l|l|}
$2,032,966,275$ \\
\end{tabular} & $25.21 \%$ & 1.20 & 1.91 \\
\hline & $50 \%$ & $(580,112,704)$ & $2.52 \%$ & 1.05 & 3.86 \\
\hline & $75 \%$ & $(3,193,191,684)$ & \#NUM! & 0.92 & -135.40 \\
\hline \multirow[t]{3}{*}{ Price Decreased by .... } & $25 \%$ & $90,469,819$ & $8.90 \%$ & 1.09 & 3.32 \\
\hline & $35 \%$ & $(1,731,760,355)$ & $-14.20 \%$ & 0.96 & 9.55 \\
\hline & $50 \%$ & $(4,465,105,617)$ & \#NUM! & 0.75 & -5.28 \\
\hline
\end{tabular}

\section{Five Forces Porter Analysis}

Competitiveness can be defined as a firm's success in comparison with other firms in the industry, national and international scene. According to the internationalization of markets, the loss of long distances and countries borders and simplify the entry of firms to international competition than in previous decades. On 1980s, Porter introduce Porter's Competitiveness model and known as Porter's five forces

The concept expressed by Michael Porter in "Porter's five forces" can be used for analysis of the industry and the development of corporate strategies to see the attractiveness of the market. The attractiveness of the market in this context refers to the profitability of the industry. The industry cannot be "attractive" when the combination of the power of moving lower overall profitability, whereas when market conditions the industry moving toward "pure competition" then the industry is considered really unattractive.

Globally, the use of Porter's Five Forces model involves a continuous process of environmental scanning and monitoring as well as obtaining competitive intelligence on present and potential rival banks. This is why many industry use scenario planning to anticipate and respond to volatile and disruptive environmental changes. Strategic management identifies the general environment and the competitive environment [6]

Although many scholars and practitioners at both the international and local levels still highly value and use Porter's Five forces model, there has been a high level of debate on the application of this model to the complex contemporary industry environment with rapid changes and technological advancement. Some scholars argue that the advance of internet has done much in changing the industry environment and thus challenging the five forces model. They argue that before the advent of the internet, every industry consisted of a physical part and an informational set and the informational set was difficult to handle and access. This makes them to further point that Porter's argument that in as much as the five underlying forces of competition determine the industry attractiveness, it has also been challenged by its failure to explain the expansion of the distance learning industry [7]

On this research, we are still using model porter in this research with the consideration, that the object of this research still relevant if it is analyzed using the model. Developed Product is a product with quite innovation levels, but the impact on the model of free market competition where the limits of the market are not visible due to the development of information technology $\sim$ does not give significant effects against products since the product recognize as traditional products based, although quite different form with the original product

Porter's five competitive forces are depicted in Figure 1. Porter's starting point was that he wanted to account for longterm variances in the economic returns of one industry versus another. There are 5 five explanatory or causal variables to explain superior and inferior performance, through: [8]

1. The bargaining power of the buyers.

2. Entry barriers.

3. Rivalry.

4. Substitutes.

5. The bargaining power of the suppliers. 


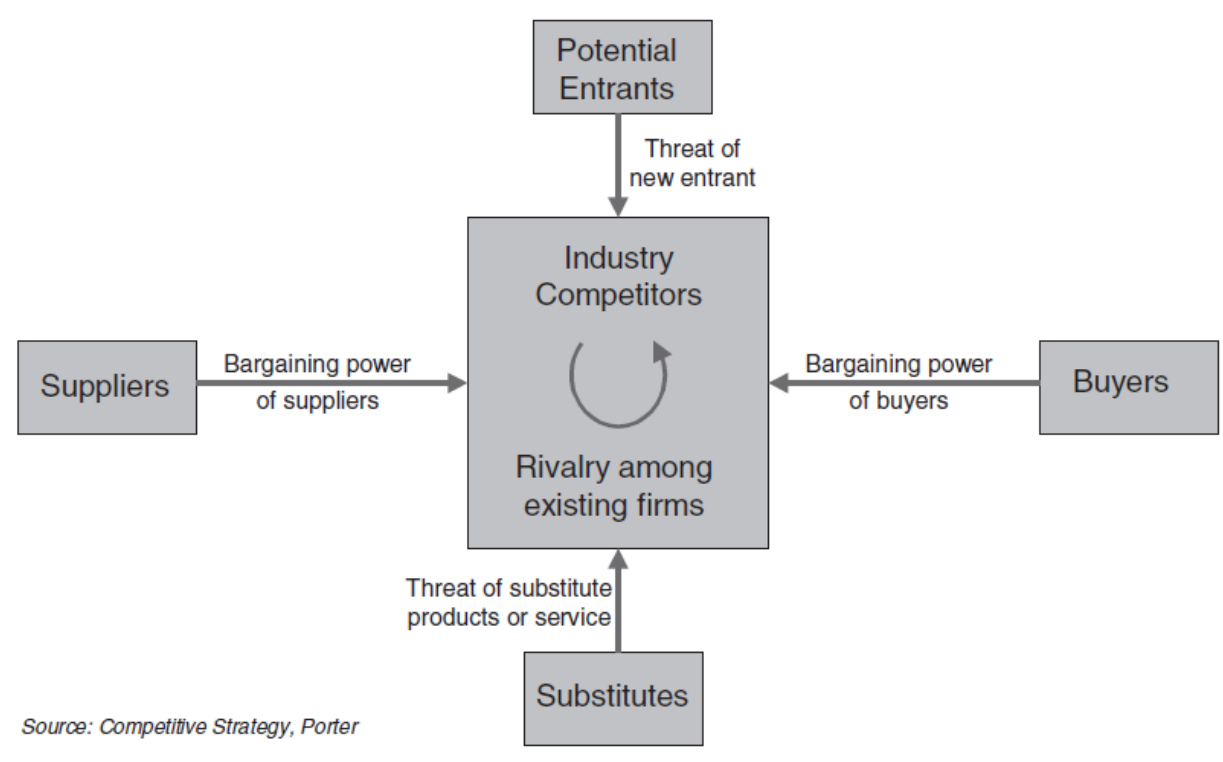

Figure 1. Porter's five forces model

The five forces determine industry profitability because they influence the price, cost and required investment of firms in an industry (element of return on investment) [9]. Buyer power influences the prices that firm can charge, for example, as does the threat of substitution. The power of buyers can also influence cost and investment, because powerful buyers demand costly service. The bargaining power of suppliers determines the cost of raw materials and other inputs. The intensity of rivalry influences prices as well as the costs of competing in area such as plant, product development, advertising, and sales forces. The threat of entry places a limit on prices, shape the investment required to deter entrants.

\subsection{Bargaining power of the buyers}

Powerful customers, who are on the other side of powerful suppliers. Able to achieve greater value by being forced to reduce prices, demanding better quality or more services and collaboration with other actors. If buyers are powerful, they are able to have a high bargaining power, especially if they are sensitive to prices. [10]

The higher in the number of buyers, the bargaining power of buyers is reduced. This product, the number of buyers can be assumed equal to the segment of the market of the product. The product is a new product developed by a specific segment, i.e. to the consumers who have special needs such as vegetarians but these products can be consumed by a wide segment of consumers. With such a condition, it can be said that the number of consumers is limited.

This condition is related to purchase volumes, the higher purchase volume of buyers, increase their bargaining power and the lower the purchase volume of buyers, and reduce their bargaining power. With limited consumer segment, will have an impact on the possible purchase of products by consumers with large quantities, this resulted in the bargaining position for the buyers will increase.
However, there are some factors that can increase the bargaining position of the product. such as the Rate of Vitality Product Factors $\sim$ the product is more important to the buyer, the buyer's bargaining power increases and the product is more vital $\sim$ is one factor that enhances the bargaining position of the product, it is influenced by market segment on the vegetarian group, as a high protein beverage product. One source of the protein consumed by vegetarians comes from beans but products made from bean have limitation, they have a long chain of amino acids, so it is not easy to digest. While this product is easily digest because it's made from tempeh which has through fermentation process in order to break the chain of amino acids making it easily digestible.

Other factors influencing the bargaining position of the buyer is the substitute product. For vegetarians, this product is a new formulation because up to this moment there has been no similar products which have tempeh based product which contain high protein as beverage products. Thus, there has been no similar competitor can affect the bargaining positions of the consumer.

\subsection{Threat of New Entrants}

New entrants of one industry bring new capacity for themselves and tend to gain market share. That it is a lot of pressure on prices, costs and necessary investment rates to compete. Specifically, when the new entrants begin to diversify their products for entering to other markets, they can expand the existing capabilities and use the new cash flows to increase competition.

Threat of entry in an industry depends on the height of entry barriers and reaction of new entrants. If barriers to entry are low, allow new entrants to quickly become a rival. The threat of entry will be very high and the profitability of the industry. Thus, the threat of entry did not prevent its entry, but seriously lowered profitability. 


\section{PRESS}

It had been revealed earlier that this is a new product, a new market niche, and there is no competitor, and threat will come soon when the product already exists in the market, along with the newcomers enter to the market that has been created. So at the time this product was received well by the market, to create a high entry barrier for competitors is to maintain quality, the price and expectations of consumers against these products as well as the mastery of technological process.

\subsection{Rivalry among Existing Competitors}

Competitive intensity refers to the amount of domestic and international competition. According to Bekly international theory, until development costs in the domestic market aren't more than the cost of developing the international market, companies operate in the domestic market. When domestic markets are saturated, this case will happen. [11]

With its position as a new product and there has been no similar competitor, this is not something that is good in the long period of time. It takes one or more competitor that can serve as a trigger for improvement and stabilization of the market against these products. With the existence of a competitor, the mechanism of competition in the market will be developed, such as the determination of the strategy of price competition, promotion, quality, new product development, brand identity and so on. Thing to do is to create competition through opening the markets for attract competitor to enter the segment of this product.

\subsection{Threat of Substitute Products}

The products may look different in appearance, but they have the potential that as a substitute products, attract the customer's satisfaction. The position of this product, is actually as product substitution for vegetarians who have less choice of beverage products high in protein. Although the beverage products high in protein such as soy milk that becomes one of the popular products by vegetarian groups. However, it have the disadvantage of storage time product and digestibility, known as derived from soy beans that still has a long chain of amino acids.

\subsection{Bargaining Power of Suppliers}

In a competitive industry, suppliers as well as buyers, can have bargaining power. Suppliers, when they see the buyer, have less of a choice power. With its ability, to increase the price or reduce the quality of purchased goods and services can impact an industry. Powerful suppliers, the more value they have for themselves where to set higher prices, limiting quality of services or shift costs to industry participants. Powerful suppliers, including suppliers of labor, can be in their power, the profitability of an industry. So that by raising prices to cover their costs.

According to data of the Ministry of industry, by 2015 was recorded approximately 115.000 tofu and tempeh SME's, with most of the concentration is on the island of Java. This provides an overview of the major raw material supplier of this product is quite a lot. With this condition, the bargaining position against the supplier will be strong, because there are so many options for supplier of raw materials. However, the concern is not only the price but also the quality of the raw material need to maintain because this will impact to quality of the product.

Porter also identified the specific generic strategies for countering the five industry forces as a mention in table 2 .

Table 2. Porter's Generic Strategies

\begin{tabular}{|c|c|c|c|}
\hline \multirow{2}{*}{$\begin{array}{l}\text { Industry } \\
\text { Force }\end{array}$} & \multicolumn{3}{|c|}{ Generic Strategies } \\
\hline & Cost Leadership & Differentiation & Focus \\
\hline $\begin{array}{l}\text { Entry } \\
\text { Barriers }\end{array}$ & $\begin{array}{l}\text { Ability to cut price in } \\
\text { retaliation deters } \\
\text { potential entrants. }\end{array}$ & $\begin{array}{l}\text { Customer loyalty can } \\
\text { discourage potential entrants. }\end{array}$ & $\begin{array}{l}\text { Focusing develops core competencies that } \\
\text { can act as an entry barrier. }\end{array}$ \\
\hline $\begin{array}{l}\text { Buyer } \\
\text { Power }\end{array}$ & $\begin{array}{l}\text { Ability to offer lower } \\
\text { price to powerful } \\
\text { buyers. }\end{array}$ & $\begin{array}{l}\text { Large buyers have less power to } \\
\text { negotiate because of few close } \\
\text { alternatives. }\end{array}$ & $\begin{array}{l}\text { Large buyers have less power to negotiate } \\
\text { because of few alternatives. }\end{array}$ \\
\hline $\begin{array}{l}\text { Supplier } \\
\text { Power }\end{array}$ & $\begin{array}{l}\text { Better insulated from } \\
\text { powerful suppliers. }\end{array}$ & $\begin{array}{l}\text { Better able to pass on supplier } \\
\text { price increases to customers. }\end{array}$ & $\begin{array}{l}\text { Suppliers have power because of low } \\
\text { volumes, but a differentiation-focused } \\
\text { firm is better able to pass on supplier } \\
\text { price increases. }\end{array}$ \\
\hline $\begin{array}{l}\text { Threat of } \\
\text { Substitutes }\end{array}$ & $\begin{array}{l}\begin{array}{l}\text { Can use low price to } \\
\text { defend } \\
\text { substitutes. }\end{array} \\
\end{array}$ & $\begin{array}{l}\text { Customer's become attached to } \\
\text { differentiating attributes, } \\
\text { reducing threat of substitutes. }\end{array}$ & $\begin{array}{l}\text { Specialized products \& core competency } \\
\text { protect against substitutes. }\end{array}$ \\
\hline Rivalry & $\begin{array}{l}\text { Better able to compete } \\
\text { on price. }\end{array}$ & $\begin{array}{l}\text { Brand loyalty to keep customers } \\
\text { from rivals. }\end{array}$ & $\begin{array}{l}\text { Rivals cannot meet differentiation- } \\
\text { focused customer needs. }\end{array}$ \\
\hline
\end{tabular}

Sources: Indiasty, et.al [12]

Generic strategic in the table is intended to facilitate the decision making for the company. By using the table, the two analyses that can be used both approaches complement each other economic viability or diamond frame porter. 


\section{PRESS}

From the analysis of the sensitivity, reflected that there are 2 variables that influence significantly to the sustainability of the business, i.e. selling prices and changes in variable cost of production.

The decrease in selling price only has a tolerance of $25 \%$, if the number exceeds the tolerance can be ensured that the business is not worth it. Similarly, the number of production cost tolerance also has a $25 \%$ tolerance.

How to suppress the influx of competitors is to set a fairly high barrier of entry, such as by setting the selling price which cannot be followed by competitors, and reducing the sales price is one of the strategy that should adopt. But based on the analysis, reducing the sales product more than $25 \%$ Indicate that the business is not feasible anymore.

Market segmentation of product are vegetarians, it means that the company would have to make an effort to create loyal consumer of this product.

\section{CONCLUSION}

This study showed that Business Analysis on sweet condensed tempeh on cash flow analysis has demonstrated that the operation of the plant would be financially feasible. The calculations of the financial analysis resulted in a net present value (NPV) of IDR 4.64 billion, a $46.33 \%$ internal rate of return (IRR), a cost benefit ratio (BCR) of 1.42 and a payback period less than two years

According to Porter's five Forces, bargaining power of the buyers is high, since the product has a limited market segment. But base on strategy, there are non-optional product since the product is new and has no competitor yet. With these situation, for the buyers, there is no reason not to buy this product as long the company successfully in educating the market.

Since the product is new and doesn't have any competitor yet, the company should setting early high entry barrier for competitor by maintain quality, mastering in production process and the price and expectations of consumers. But this is not something that is good in the long period of time. It takes one or more competitor that can serve as a trigger for improvement and stabilization of the market against these products, and company should create their own enemy.

For bargaining power of supplier, there are so many options for supplier of raw materials but the concern is how to maintain the quality of the tempeh as raw material.

Since the segmentation of product are limited, it means that the company would have to make an effort to create loyal consumer of this product.

\section{ACKNOWLEDGMENT}

The author would like to thank The Chief of Technology Incubation and Technology Transfer and IPR Management Center for Innovation Indonesia Institute of Sciences, Chief of Research Unit for Natural Product Technology Indonesia Institute of Sciences, speakers and informants who have provided information and discussions during data collection. And also or the use of facilities and equipment as well as to
Center for Innovation for the supports in completing this research.

\section{REFERENCES}

[1] Barus, T., Suwanto, A., Wahyudi, A. T. and Wijaya, H. 2008. Role of bacteria in tempe bitter taste formation; microbiological and molecular biological analysis based on 16S rRNA gene. Microbiology Indonesia 2: 17-21.

[2] Seumahu, C. A., Suwanto, A., Rusmana, I. and Solihin, D. 2013. Bacterial and fungal communities in tempeh as reveal by amplified ribosomal intergenic sequence analysis. Hayati Journal of Biosciences 20(2): 65-71.

[3] Angwar, M., Pudjiono, P.I., Herdian, H., 2015, Sari Tempe Kental Manis dan Proses Pembuatannya, LIPI Indonesia, IDP000037654.

[4] Sugiyono. (2009). Metode Penelitian Kuantitatif dan Kualitatif. CV.Alfabeta: Bandung.

[5] Razgaitis, R. (2009). Valuation \& Deal Making of Technology-Based Intellectual Property, John Willey \& Sons, New Jersey, pp 235-331.

[6] Dess, G. G., Lumpkin, G. T. and Eisher, A. B (2006). Strategic Management. Text and cases. International edition. London: McGraw-Hill.

[7] Karagiannopoulos, G. D., Georgopoulos, N., and Nikolopoulos, K (2005) 'Fathoming Porter's five forces model in the internet era'. Info Journal. Vol.7 No.6 (2005), pp.66-76. Emerald Group Publishing Limited

[8] Porter EM. 1980. Competitive Strategy. The Free Press/Macmillan: New York

[9] Grundy, Tony, (2006) "Rethinking and reinventing Michael Porter's five forces model" from Strategic Change 15 (5) pp.213-229, Chichester: Wiley.

[10] Eskandari, M.J., Miri, M., Gholami, S., Sajadi, H.R (2015). Factors Affecting The Competitiveness Of The Food Industry By Using Porter's Five Forces Model Case Study In Hamadan Province, Iran. Journal of Asian Scientific Research, 2015, 5(4):185-197

[11] E. Karadeniz and K. Göćer, "Internationalization of small firms: A case study of Turkish small- and medium sized enterprises," European Business Review, vol. 19, pp. 387403, 2007.

[12] Indisatsy, C.M., Mwangi, M.S., Mandere, E.N., Bichanga, J.M., George, G.E. (2014). The Application of Porter's Five Forces Model on Organization Performance: A Case of Cooperative Bank of Kenya Ltd, European Journal of Business and Management, Vol.6, No.16, pp 75-85. 